doi: $10.2306 /$ scienceasia1513-1874.2013.39.610

\title{
Anti-inflammatory and anticancer activities of (-)-zeylenol from stems of Uvaria grandiflora
}

\author{
Phikunkeaw Seangphakdee $^{\mathrm{a}}$, Wilart Pompimon ${ }^{\mathrm{a}}$, Puttinan Meepowpan ${ }^{\mathrm{b}}$, Ampai Panthong $^{\mathrm{c}}$, \\ Natthakarn Chiranthanut $^{\mathrm{d}}$, Ratana Banjerdpongchai ${ }^{\mathrm{e}}$, Benjawan Wudtiwai ${ }^{\mathrm{e}}$, Narong Nuntasaen ${ }^{\mathrm{f}}$, \\ Siripit Pitchuanchom ${ }^{\mathrm{a}, *}$ \\ a Laboratory of Natural Products, Faculty of Science and Centre for Innovation in Chemistry, \\ Lampang Rajabhat University, Lampang, Thailand \\ b Department of Chemistry and Centre for Innovation in Chemistry, Faculty of Science, \\ Chiang Mai University, Chiang Mai, Thailand \\ c Department of Pharmacology and Centre for Innovation in Chemistry, Faculty of Medicine, \\ Chiang Mai University, Chiang Mai, Thailand \\ d Department of Pharmacology, Centre of Thai Traditional and Complementary Medicine, \\ Faculty of Medicine, Chiang Mai University, Chiang Mai, Thailand \\ e Department of Biochemistry, Faculty of Medicine, Chiang Mai University, Chiang Mai, Thailand \\ f The Forest Herbarium, Department of National Park, Wildlife and Plant Conservation, \\ Ministry of Natural Resources and Environment, Bangkok, Thailand
}

${ }^{*}$ Corresponding author, e-mail: meen2@hotmail.com

Received 19 Apr 2013

Accepted 16 Jul 2013

\begin{abstract}
Uvaria grandiflora has stimulated rigorous phytochemical investigation aimed at determining chemical structures and biological activities. In recent years, many polyoxygenated cyclohexenes have been isolated from this genus. This study reports that zeylenol isolated from the stems of $U$. grandiflora possess potential anti-inflammatory, anticancer, and caspase- 3 activities. The structure of this compound was elucidated from spectroscopic analysis, particularly 2D NMR techniques. The anti-inflammatory effect and toxicity of zeylenol were evaluated in animal models and compared to that of reference drugs. In addition, the cytotoxicity of the isolated compound against human breast cancer MDA-MB231 and hepatocellular carcinoma HepG2 cell lines were studied. The test (-)-zeylenol at the dose of $1 \mathrm{mg} / \mathrm{ear}$ significantly inhibited oedema formation by $90 \%, 69 \%, 52 \%$, and $52 \%$ after $15,30,60$, and $120 \mathrm{~min}$, respectively. Zeylenol was found to be toxic to both MDA-MB231 and HepG2 cells in a dose response manner with $\mathrm{IC}_{50}$ values of $54 \pm 10$ and $>80 \mu \mathrm{M}$, respectively. The compound induced MDA-MB231 cell apoptosis via caspase- 3 activation. Zeylenol probably possesses anti-inflammatory activity by inhibiting the synthesis or release of various inflammatory mediators and might be used to induce human breast cancer MDA-MB231 cell apoptosis.
\end{abstract}

KEYWORDS: cytotoxicity, MDA-MB231, HepG2, caspase-3 activity, Annonaceae

\section{INTRODUCTION}

The genus Uvaria, one of the largest palaeotropical genera in the family Annonaceae, comprises more than 220 species distributed in wet tropical regions of Africa, Madagascar, southeast Asia, northern Australia, and Melanesia. In Thailand, U. grandiflora is found in the south and southeast regions. Plants in this genus have been studied for bioactive constituents and various classes of compounds including alkaloids, annonaceous acetogenins, flavonoids have been isolated. Several compounds from this genus show antimalarial, antitumour, pesticidal and other biological activites ${ }^{1-4}$.
U. grandiflora is a hardwood forest vine, large, and sticky. A single flower at the end of twig reaches $6-12 \mathrm{~cm}$ diameter when blooming. Phytochemical investigation of $U$. grandiflora demonstrated the presence of several groups of natural chemical, including polyoxygenated cyclohexenes and aromatic derivatives, also showed interesting antitumour, antimalarial $^{1-4}$, and antipancreatic cancer activities ${ }^{5,6}$. Polyoxygenated cyclohexenes have a rather simple molecular skeleton of 1-methylcyclohex-4-ene. However, they contain multiple oxygenic substituents, such as benzoxy, hydroxyl, alkoxy, epoxyl, and acetoxyl groups with abundant stereoisomers ${ }^{7-9}$. Previously, zeylenol has been reported to occur in two configura- 

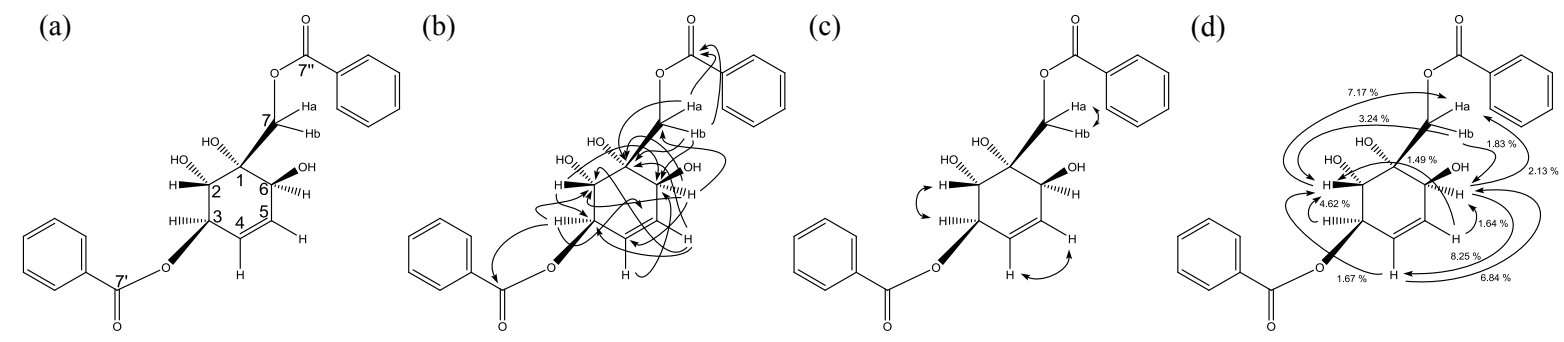

Fig. 1 (a) Structure of zeylenol together with significant correlations in the (b) HMBC, (c) COSY and (d) NOE spectra.

tions as (-)-zeylenol and (+)-zeylenol from various species of the $U$. genus and other genera ${ }^{10,11}$. In the current study, we reported the isolation, structural elucidation, anti-inflammatory and anticancer evaluation of (-)-zeylenol (Fig. 1), a polyoxygenated cyclohexene derivative which was isolated from an ethyl acetate extract of stems of $U$. grandiflora.

\section{MATERIALS AND METHODS}

\section{General experimental procedures}

Column chromatography (CC) was carried out over silica gel (70-230 mesh, MERCK). Fractions obtained from CC were monitored by TLC (pre-coated silica gel $\left.60 \mathrm{~F}_{254}, 20 \times 20 \mathrm{~cm}, \mathrm{MERCK}\right)$. UV spectrum was obtained on a Shimadzu UV-1601 spectrophotometer with ethanol as solvent. Melting point was measured on a Büchi 322 micro melting point apparatus and was uncorrected. Optical rotation was determined with a JASCO DIP-370 digital polarimeter. IR spectrum ( $\mathrm{KBr}$ disk) was recorded on Shimadzu 8900 FTIR spectrophotometer. High resolution mass spectrum (HRESIMS) was measured on a micromass Q-TOF-2 (Waters) spectrometer. Low resolution mass spectrum was recorded on a Thermo Finnigan Polaris $\mathrm{Q}$ mass spectrometer. NMR spectroscopic data were obtained from a Bruker DPX 400 spectrometer. The chemical shifts were recorded in $\delta$ values and referenced to tetramethylsilane as the internal standard.

\section{Plants material}

The stems of $U$. grandiflora were collected from Trang Province of Thailand in October 2010 and identified by Narong Nuntasaen. A voucher specimen (BKF 132441) was deposited at Forest Herbarium, Department of National Park, Wildlife and Plant Conservation, Ministry of Natural Resources and Environment, Bangkok, Thailand.

\section{Phytochemical characterization}

Air-dried powders of stems of $U$. grandiflora $(2.2 \mathrm{~kg})$ were extracted successively at room temperature with hexane, ethyl acetate, and methanol $(3 \times 51$ for each solvent). Further separations of ethyl acetate extract (56.63 g) by silica gel CC was carried out, eluted with a gradient system between hexane and ethyl acetate to afford eight fractions. The fraction six was rechromatographed by the same procedure to yield five subfractions. The precipitate in the subfraction three was recrystallized from ethanol to obtain the isolated compound as a white solid (300 mg). Based on the comparison of its spectrometric data, e.g., MS, IR, UV, ${ }^{1} \mathrm{H},{ }^{13} \mathrm{C}$ NMR together with 2D NMR (HMBC, COSY and NOE) experiments to those reported in the literature, compound was identified to be (-)-zeylenol ${ }^{10}$ (Fig. 1).

(-)-Zeylenol as an isolated compound had the molecular formula $\mathrm{C}_{21} \mathrm{H}_{20} \mathrm{O}_{7}$, deduced from the HRESIMS (found $m / z 385.1300[\mathrm{M}+\mathrm{H}]^{+}$). The UV spectrum showed maxima at 274 and $231 \mathrm{~nm}$, suggesting an extended benzoyl chromophore. The IR spectrum showed the presence of hydroxyl groups (strong absorption at $3469 \mathrm{~cm}^{-1}$ ), ester groups (strong absorption at $1693 \mathrm{~cm}^{-1}$ ), and monosubstituted phenyl rings $\left(1600,1585\right.$, and strong absorption $711 \mathrm{~cm}^{-1}$ ). The EIMS at $m / z 105$, benzylium ion of zeylenol formed by the cleavage of the ester groups. Moreover, a peak at $m / z 77$ formed by competitive cleavage of the $\mathrm{C}-1^{\prime \prime}, \mathrm{C}-7^{\prime \prime}$ or $\mathrm{C}-1^{\prime}, \mathrm{C}-7^{\prime}$ also supported the presence of phenyl groups in the structure.

The presence of two benzoyl groups was confirmed by the aromatic proton signals $\delta$ 7.32-7.96 $(10 \mathrm{H}, \mathrm{dd})$. The typical methylene protons bearing benzoyloxy group appeared at $\delta 4.86(\mathrm{~d}, J=12.3 \mathrm{~Hz}$, $1 \mathrm{H})$ and $\delta 4.70(\mathrm{~d}, J=12.3 \mathrm{~Hz}, 1 \mathrm{H})$. The ${ }^{1} \mathrm{H}$ NMR spectrum also showed two olefinic protons at $\delta 5.98$ (ddd, $J=10.2,3.8,1.6 \mathrm{~Hz}, 1 \mathrm{H}$ ) and $\delta 5.82(\mathrm{dd}$, $J=10.2,2.9 \mathrm{~Hz}, 1 \mathrm{H})$, three carbinyl protons at $\delta 4.38(\mathrm{~m}, 1 \mathrm{H}), \delta 4.27(\mathrm{t}, J=4.4 \mathrm{~Hz}, 1 \mathrm{H})$ and $\delta 5.70(\mathrm{~m}, 1 \mathrm{H})$. The key HMBC correlations from methine proton $\mathrm{H}-6(\delta 4.38)$ to $\mathrm{C}-4(\delta 126.5)$ and $\mathrm{H}-$ $3(\delta 5.70)$ to $\mathrm{C}-5(\delta$ 130.1) supported that the double bond located at C-4/C-5. The HMBC correlations of $\mathrm{H}-7 \mathrm{a}$ and $\mathrm{H}-7 \mathrm{~b}$ to the ester carbonyl at $\delta_{c} 167.7$ and H-3 to ester carbonyl $\delta_{c} 167.1$ indicated that the two 
benzoxyl groups located at $\mathrm{C}-1$ and $\mathrm{C}-3$, respectively. Further, in the ${ }^{13} \mathrm{C}$ NMR spectrum, one carbon of tertiary alcohol resonated at $\delta 75.9(\mathrm{C}-1)$ and one carbon of secondary alcohol resonated at $\delta 70.7$ (C2). In the COSY spectrum, a strongly proton triplet at $\delta 4.27(\mathrm{H}-2)$ showed coupling to methine proton absorption at $\delta 5.7(\mathrm{H}-3)$ and olefinic proton $\delta 5.82$ $(\mathrm{H}-4)$ with proton $\delta 5.98(\mathrm{H}-5)$ and methylene proton $\mathrm{H}-7 \mathrm{a}(\delta 4.86)$ with proton $\mathrm{H}-7 \mathrm{~b}(\delta 5.70)$, respectively.

Furthermore, on the basis of 1D NOE NMR experiment of zeylenol, it was established that the hydroxyl group (C-2) and benzoxyl group (C-3) were both axial, i.e., $\beta$-configuration. Moreover, the relative configuration between $\mathrm{H}-2$ and $\mathrm{H}-7 \mathrm{a}$ of benzoyloxy moiety was also established as cis-configaration. This structure corresponds to zeylenol as reported by Pan et $\mathrm{al}^{7}$ and Jolad et al ${ }^{10}$.

Zeylenol: White needle crystals, m.p. 110.1$112.2^{\circ} \mathrm{C} ;[\alpha]_{\mathrm{D}}^{25}-41.16^{\circ}\left(c=0.26, \mathrm{CHCl}_{3}\right) ; \mathrm{UV}$ $\lambda_{\max }(\mathrm{EtOH}) \mathrm{nm}(\log \varepsilon): 274$ (4.66) and 231 (5.46); ${ }^{1} \mathrm{H}-\mathrm{NMR}\left(\mathrm{CDCl}_{3}\right) \delta: 7.96-7.32(5 \mathrm{H}, \mathrm{dd}, J=8.2$, $0.8 \mathrm{~Hz}), 7.91-7.34(5 \mathrm{H}, \mathrm{dd}, J=8.2,0.8 \mathrm{~Hz}), 5.98$ $(1 \mathrm{H}, \mathrm{ddd}, J=10.2,3.8,1.6 \mathrm{~Hz}), 5.82(1 \mathrm{H}, \mathrm{dd}$, $J=10.2,2.5 \mathrm{~Hz}), 5.70(1 \mathrm{H}, \mathrm{m}), 4.86(1 \mathrm{H}, \mathrm{d}, J=$ $12.3 \mathrm{~Hz}), 4.70(1 \mathrm{H}, \mathrm{d}, J=12.3 \mathrm{~Hz}), 4.38(1 \mathrm{H}$, br.t, $J=3.9 \mathrm{~Hz}), 4.27(1 \mathrm{H}, \mathrm{t}, J=4.9 \mathrm{~Hz}) .{ }^{13} \mathrm{C} \mathrm{NMR}$ $\left(\mathrm{CDCl}_{3}\right) \delta: 167.7$ (s), 167.1 (s), 133.4 (d), 133.3 (d), 130.1 (d), 129.8 (s), 129.7 (d), 129.4 (d), 129.3 (s), 128.4 (d), 128.3 (d), 126.5 (d), 75.9 (s), 73.9 (d), 70.7 (d), $68.8(\mathrm{~d}), 66.6$ (t). IR (KBr) cm $\mathrm{cm}^{-1}: 3469,1693$, $1600,1585,1452,1317,1282,1120,1072,711$. EIMS $m / z:$ 384(0.32), 215(6), 202(2), 131(1), 121(8), 105(100), 77(70), 50(20). HRESIMS (found $\mathrm{m} / \mathrm{z}$ $\left.385.1300[\mathrm{M}+\mathrm{H}]^{+}\right)$.

\section{Animals}

Male Sprague-Dawley rats weighing 40-60 g purchased from the National Laboratory Animal Centre, Nakorn Pathom Province, Thailand, were used. All animals were kept in a room maintained under environmentally controlled conditions of $24 \pm 1^{\circ} \mathrm{C}$ and $12 \mathrm{~h}$ light $12 \mathrm{~h}$ dark cycle. The animals had free access to water and food. They were acclimatized at least 1 week before starting the experiments. The experimental procedure was approved by Animal Ethics Committees, Faculty of Medicine, Chiang Mai University, Thailand. (Internal protocol number 26/2551, approved on 5 Feb 2009).

\section{Anti-inflammatory effect}

Oedema was assessed with the method of Brattsand et $\mathrm{al}^{12}$. Male rats weighing $40-60 \mathrm{~g}$ were used. Ear oedema was induced by the topical application of either EPP dissolved in acetone to the inner and outer surfaces of both ears by means of an automatic microlitre pipette. Test zeylenol, at the dose of $1 \mathrm{mg} / \mathrm{ear}$, were dissolved in acetone and applied topically in a volume of $20 \mu \mathrm{l}$ to the inner and outer surfaces of the pina just before the irritants. The control group received acetone.

\section{Cell culture}

The human hepatocellular carcinoma HepG2 and breast cancer MDA-MB231 cells were cultured in Leibovitz's L-15 and Dulbecco's modified eagle media (DMEM), respectively, with $25 \mathrm{mM} \mathrm{NaHCO}_{3}, 20 \mathrm{mM}$ HEPES, 100 units $/ \mathrm{ml}$ penicillin, $100 \mu \mathrm{g} / \mathrm{ml}$ streptomycin and supplemented with $10 \%$ foetal bovine serum. The cell lines were grown at $37^{\circ} \mathrm{C}$ in a $5 \%$ $\mathrm{CO}_{2}$ atmosphere. The cells $\left(1 \times 10^{3}\right)$ were treated with the purified compounds at indicated concentrations for $24 \mathrm{~h}$. The (-)-zeylenol compound was dissolved in DMSO as a vehicle and the maximum volume used did not exceed $10 \mu \mathrm{l} / \mathrm{ml}$ of media.

\section{Cytotoxicity test}

Following zeylenol treatment, cell viability was assessed by the MTT (3-(4,5-dimethyl)-2,5-diphenyl tetrazolium bromide) assay ${ }^{13}$. This method is based on the ability of viable cells to reduce MTT and form a blue formazan product. MTT solution (sterile stock solution of $5 \mathrm{mg} / \mathrm{ml}$ ) was added to cell suspension to a final concentration of $100 \mu \mathrm{g} / \mathrm{ml}$ and the solution incubated for $4 \mathrm{~h}$ at $37^{\circ} \mathrm{C}$ in a humidified $5 \% \mathrm{CO}_{2}$ atmosphere. The medium was then removed and the cells were treated with DMSO for $30 \mathrm{~min}$. The optical density (OD) of the cell lysate was measured at $540 \mathrm{~nm}$, with a reference wavelength of $630 \mathrm{~nm}$, using a microtitre plate reader (Biotek, USA). The number of viable cells was calculated from the number of untreated cells, and the data were expressed as percentage cell viability:

$$
\text { cell survival }=\frac{\text { OD of sample }}{\text { OD of control }} \times 100 \% .
$$

\section{Assay of caspase-3 activity}

Cleavage of the fluorogenic peptide substrate DEVDAMC (indicative of caspase-3-like enzyme activity) was estimated ${ }^{14}$. Cell lysates $\left(1 \times 10^{6}\right.$ cells $)$ and substrate $(50 \mathrm{mM})$ were combined in a standard reaction buffer and added to a 96-well plate. Enzyme-catalysed release of AMC was measured by a fluorescence plate reader (Bio-tek, USA) using $355 \mathrm{~nm}$ excitation and $460 \mathrm{~nm}$ emission wavelengths. 


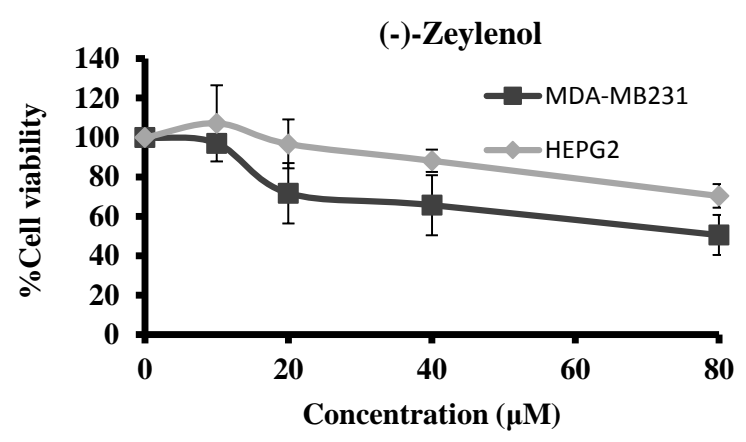

Fig. 2 Cytotoxic effects of (-)-zeylenol on human breast cancer MDA-MB231, hepatocellular carcinoma HepG2 cell lines and MDA-MB231 or HepG2 cells were treated with the compound at various concentrations for $24 \mathrm{~h}$ and then the cell viability was determined by the MTT assay. The values were expressed as mean \pm S.D. from triplicates of three independent experiments.

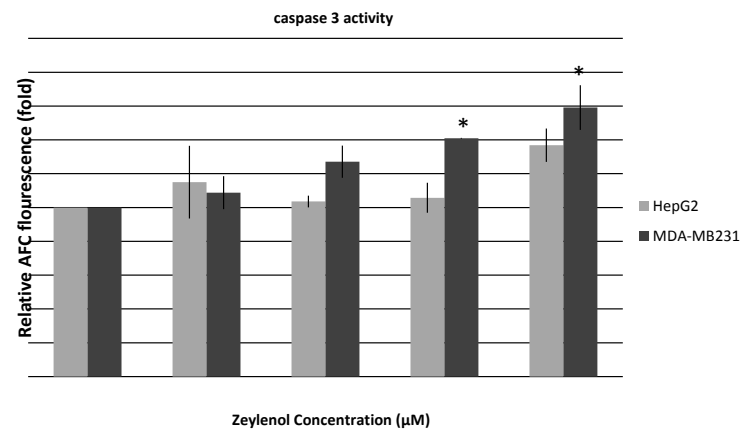

Fig. 3 Caspase-3 activity which was induced by (-)-zeylenol in HepG2 and MDA-MB231 cells. HepG2 and MDA-MB231 cells were treated with the compound at various concentrations for $24 \mathrm{~h}$ and the caspase- 3 activity was determined according to the method described in materials and methods. *, $p<0.05$ as compared to control.

\section{Statistical analysis}

All data were expressed as mean \pm SE. Statistical comparison between groups was analysed by using one-way ANOVA and $p$ values of less than 0.05 were considered significant.

\section{RESULTS}

(-)-Zeylenol was evaluated for anti-inflammatory and cytotoxic activities. It was found that this compound showed similar anti-inflammatory activity as that observed for phenylbutazone (Table 1).

Moreover, (-)-zeylenol exhibited moderate cytotoxic activity in human breast cancer MDA-MB231 at $\mathrm{IC}_{50} 54.22 \mu \mathrm{M}$ with SD 10.20 but with a lesser extent in hepatocellular carcinoma HepG2 (Fig. 2). The caspase-3 activity, which increases in apoptotic cell death is a common effector proteolytic cysteine protease, increased significantly in MDA-MB231 cells (Fig. 3). This indicates cell death occur by apoptosis.

\section{DISCUSSION}

\section{Anti-inflammatory effect}

The ear oedema thickness of the rats in the control group increased gradually and peaked at 30 and 60 min after EPP application. The oedema persisted for $2 \mathrm{~h}$ during the assessment. Phenylbutazone, at a dose of $1 \mathrm{mg} / \mathrm{ear}$, was used as a positive control, and it significantly reduced the oedema formation at all assessment times. The test zeylenol significant inhibit oedema formation at the dose of $1 \mathrm{mg} / \mathrm{ear}$ at all determination times, with a similar intensity as phenylbutazone. The results of the present study reveal the anti-inflammatory activity of all test substance in the acute phase of inflammation. Formation of EPPinduced rat ear oedema is a useful model for screening and investigating the anti-inflammatory activity of test substances on the acute phase of inflammation. The inflammatory mediators released in this model include histamine, serotonin, bradykinin and prostaglandins. These mediators are capable of promoting vasodilation and increasing vascular permeability as well as synergistically producing oedema ${ }^{15}$. It was found that zeylenol elicited a significant inhibitory effect on the oedema formation at all assesement times, at the dose of $1 \mathrm{mg} /$ ear similar to that of phenylbutazone. Thus (-)-zeylenol probably possesses anti-inflammatory activity by inhibition of the release or synthesis of various inflammatory mediators.

\section{Anticancer effect}

The (-)-zeylenol was toxic to both MDA-MB231 and HepG2 cells in a dose response manner (Fig. 3) with $\mathrm{IC}_{50}$ values of $54 \pm 10$ and $>80 \mathrm{mM}$, respectively. Cell death occurred by apoptosis which is a programmed cell death indicated by the increase of caspase- 3 activity a dose-dependent fashion in MDAMB231 cell line at 40 and $80 \mu \mathrm{M}$. In HepG2 cells, the caspase- 3 activity was not significantly changed, which might indicate that the doses used were not cytotoxic to human hepatocellular cells. The maximum concentration to $\mathrm{HepG} 2$ cells was about $\mathrm{IC}_{30}$. However, less than two fold increase in caspase3 activity was observed in MDA-MB231 cell line. Furthermore, there was an overlap of error bars at $80 \mu \mathrm{M}$ for the two cell lines, indicating little difference in the effect of the compound between the two cell 
Table 1 Anti-inflammatory activity of zeylenol.

\begin{tabular}{|c|c|c|c|c|c|c|c|c|c|}
\hline \multirow[t]{2}{*}{ Group } & \multirow{2}{*}{$\begin{array}{c}\text { Dose } \\
\text { (mg/ear) }\end{array}$} & \multicolumn{4}{|c|}{ oedema thickness $(\mu \mathrm{m})$} & \multicolumn{4}{|c|}{ oedema inhibition (\%) } \\
\hline & & $15 \mathrm{~min}$ & $30 \mathrm{~min}$ & $1 \mathrm{~h}$ & $2 \mathrm{~h}$ & $15 \mathrm{~min}$ & $30 \mathrm{~min}$ & $1 \mathrm{~h}$ & $2 \mathrm{~h}$ \\
\hline control (acetone) & - & $160.0 \pm 7.3$ & $180.0 \pm 5.2$ & $203.3 \pm 8.0$ & $193.3 \pm 4.9$ & - & - & - & - \\
\hline phenylbutazone & 1 & $30 \pm 13^{*}$ & $43.3 \pm 9.5^{*}$ & $73 \pm 12^{*}$ & $90.0 \pm 4.5^{*}$ & 81 & 76 & 64 & 53 \\
\hline (-)-zeylenol & 1 & $16.7 \pm 3.3^{*}$ & $57.7 \pm 2.1^{*}$ & $98.3 \pm 8.3^{*}$ & $93.3 \pm 5.6^{*}$ & 90 & 69 & 52 & 52 \\
\hline
\end{tabular}

Results are expressed as mean $\pm \mathrm{SE}$ (number of ears $=6$ )

* Significantly different from the control group, $p<0.05$

lines. (-)-Zeylenol might be used as an alternative medicine to treat cancer cells such as human breast cancer cells (MDA-MB231) or to lessen the dose of conventional chemotherapeutic drugs in combined treatment, which will reduce the toxic side effects of classical chemotherapy. However, experiments in vivo would need to be performed before the clinical application.

Acknowledgements: Financial support from the Centre of Excellence for Innovation in Chemistry (PERCHCIC), Office of the Higher Education Commission, Ministry of Education, the Thailand Research Fund (Grant No. RMU5080003) and the National Research Council of Thailand is gratefully acknowledged.

\section{REFERENCES}

1. Pan XP, Yu DQ (1995) Two polyoxygenated cyclohexenes from Uvaria grandiflora. Phytochemistry 40, 1709-11.

2. Chen Y, Chen RY, Yu DQ (1996) Six acetogenins from Uvaria tonkinesis. Phytochemistry 43, 793-801.

3. Fleischer TC, Waigh RD, Waterman PG (1997) A novel retrodihydro from the stem bark of Uvaria mocoli. Phytochemistry 47, 1387-91.

4. Ankisetty S, Elsohly HN, Li XC, Khan SI, Tekwani BL, Smillie T, Walker L (2005) Aromatic constituents of Uvaria grandiflora. J Nat Prod 69, 692-4.

5. Awale S, Ueda JY, Athikomkulchai S, Abdelhamed S, Yokoyama S, Saiki I, Miyatake R (2012) Antiausterity agents from Uvaria dac and their preferential cytotoxic activity against human pancreatic cancer cell lines in a nutrient-deprived condition. J Nat Prod 75, 1177-83.

6. Palframan MJ, Kociok-Köhn G, Lewis SE (2011) Total synthesis of $(+)$-grandifloracin by iron complexation of a microbial arene oxidation product. Org Lett 13, 3150-3.

7. Pan XP, Chen RY, Yu DQ (1998) Polyoxygenated cyclohexenes from Uvaria grandiflora. Phytochemistry 47, 1063-6.

8. Tang SW, Sukari MA, Rahmani M, Lajis NH, Ali AM (2011) A new abietene diterpene and other constituents from Kaempferia angustifolia Rosc. Molecules 16, 3018-28.
9. Xu QM, Zou ZM, Xu LZ, Yang SL (2005) New polyoxygenated cyclohexenes from Uvaria kweichowensis and their antitumour activities. Chem Pharmaceut Bull 53, 826-8.

10. Jolad SD, Hoffman JJ, Schram KH, Cole JR (1981) Structures of zelenol and zeylene, constituents of Uvaria zeylanica (Annaonaceae). J Org Chem 46, 4267-72.

11. Palframan MJ, Kociok-Köhn G, Lewis SE (2012) Photooxygenation of a microbial arene oxidation product and regioselective Kornblum-DeLaMare rearrangement: total synthesis of zeylenols and zeylenones. Chem Eur J 18, 4766-74.

12. Brattsand R, Thalen A, Roempke K, Kallstrom L, Gruvstad E (1982) Influence of $16 \alpha, 17 \alpha$-acetal substitution and steroid nucleus fluorinated on the topical to systemic activity ratio of glucocorticoids. J Steroid Biochem 16, 779-86.

13. Banjerdpongchai R, Kongtawelert P, Khantamat O, Srisomsap C, Chokchaichamnankit D, Subhasitanont P, Svasti J (2010) Mitochondrial and endoplasmic reticulum stress pathways cooperate in zearalenone-induced apoptosis of human leukemic cells. J Hematol Oncol 3, $50-65$.

14. Wudtiwai B, Sripanidkulchai B, Kongtawelert P, Banjerdpongchai R (2011) Methoxyflavone derivatives modulate the effect of TRAIL-induced apoptosis in human leukemic cell lines. J Hematol Oncol 4, 52-63.

15. Carlson RP, O'Neill-Davis L, Chang J, Lewis AJ (1985) Modulation of mouse ear edema by cyclooxygenase and lipooxygenase inhibitors and other pharmacologic agents. Agents Actions 17, 197-204. 